\title{
THE SKINNY ON OBESITY RATES AND THE U.S. ECONOMY
}

\author{
by \\ Paul M. Sommers \\ Dylan J. Fitzpatrick \\ And \\ Erin A. Toner
}

March 2010

MIDDLEBURY COLLEGE ECONOMICS DISCUSSION PAPER NO. 10-20

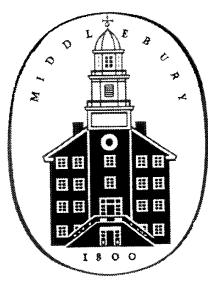

DEPARTMENT OF ECONOMICS

MIDDLEBURY COLLEGE

MIDDLEBURY, VERMONT 05753

http://www.middlebury.edu/ econ 


\title{
THE SKINNY ON OBESITY RATES AND THE U.S. ECONOMY
}

\author{
by
}

\author{
Dylan J. Fitzpatrick \\ Erin A. Toner \\ Paul M. Sommers
}

\author{
Department of Economics \\ Middlebury College \\ Middlebury, Vermont 05753
}

JEL \#: I12 


\section{THE SKINNY ON OBESITY RATES AND THE U.S. ECONOMY}

Obesity rates in the United States are among the highest in the world. In the current recession, the longest in the U.S. since World War II, some Americans have reacted to their economic woes by dropping gym memberships and showing less interest in eating healthier, both luxuries they have decided to do without. Socioeconomic factors therefore might be important predictors of obesity rates [defined as the percentage of U.S. adults with a body mass index (BMI) greater than or equal to 30]. In 2007, obesity rates were lowest in the states of Colorado (18.7 percent), Connecticut (21.2 percent), Massachusetts and Vermont (21.3 percent). Three states — Tennessee, Alabama, and Mississippi — had a prevalence of obesity greater than 30 percent.

A regression of obesity rates (OBESITY) across each of the fifty states in 2007 [ www.cdc.gov/nccdphp/dnpa/obesity/trend/maps/ ] against 2007 personal income per capita (INCOME) in thousands of dollars [ www.census.gov/statab/ranks/rank29.html ], 2007 unemployment rates (UNEMPLOYMENT) [ www.bls.gov/lau/lastrk07.htm ], and three dummy variables employed to capture regional differences produced the following results:

$$
\begin{aligned}
\text { OBESITY }= & 30.932-0.165 \text { INCOME }+0.654 \text { UNEMPLOYMENT } \\
& (13.38)(-3.06) \\
- & 3.890 \text { WEST }-1.461 \text { MIDWEST }-3.318 \text { NORTHEAST } \\
(-5.89) & (-2.21)
\end{aligned}
$$

$$
\bar{R}^{2}=.626
$$

where $t$-ratios are in parentheses.

The results show a strong negative association between obesity rates and income per capita by state $(p=.004)$. Richer states tend to have much lower obesity rates. States with relatively low unemployment rates also tend to have much lower obesity rates $(p=.014)$. The correlation between unemployment and obesity does not, however, imply causation. Obesity could carry a social stigma, preventing those who are obese 
from easily acquiring jobs. Alternatively, those who have no jobs might not have easy access to healthier food. Curiously, the number of McDonald's restaurants per 100,000 people by state ( www.csun.edu/ sg4002/research/mcdonalds_by_state.htm ) when added to the regression equation is not statistically significant $(p=.580)$.

All fifty states were divided into four Census regions: West, Midwest, South, and Northeast. After allowing for statewide differences in income per capita and unemployment rates, a regional pattern emerges. States in the South (the excluded region) have significantly higher average obesity rates (28.1 percent) than do states elsewhere [West (23.6 percent), Midwest (26.4 percent), and Northeast (23.3 percent)]. States with the largest [smallest] residual (observed obesity rate minus predicted) were Alaska (3.071 percent) and Pennsylvania (3.017 percent) [Colorado (-4.111 percent) and Florida (-3.661 percent)].

A series of two-sample $t$-tests reveals regional differences between race-specific “overweight and obesity” rates for adults with BMIs greater than or equal to 25 (www.statehealthfacts.org/). White overweight and obesity rates are significantly higher in the South compared to states in the Northeast $(p=.001)$ and West $(p=.002)$, but no higher compared to states in the Midwest ( $p=.823$ ). Nationwide, the 2007 overweight and obesity rate was higher among blacks than whites (68.9 percent $v$. 59.5 percent). Since twenty states reported insufficient data for blacks, meaningful inter-regional comparisons for blacks were not possible.

The economic downturn since these state-specific data were collected (2007) does not bode well for obesity rates. Lower incomes and lost jobs may alter the diets of affected families. In particular, the regression equation suggests that if the 4.6 percent average U.S. unemployment rate in 2007 more than doubles to 9.4 percent in 2009, then (all else equal) the national obesity rate could increase another 3.1 percent. Still higher unemployment and lower incomes mean fewer people will be eating healthier and exercising. 